\section{Isolation of Genomic DNA from Human Whole Blood}

BioTechniques 33:1231-1234 (December 2002)

Blood is the main source of DNA for genotype-related studies in humans. A rapid, efficient, and cost-effective method for the isolation of genomic DNA from whole blood is needed for screening a large number of samples. There are many published protocols $(1,3-7)$. These procedures use toxic organic chemicals (SDS-proteinase Kphenol isolation method or its modifications) $(1,3)$ and/or are time consuming $(3,4,7)$. A procedure of Sambrook and Russell (6) is one of the simplest of all the published methods. Following this procedure, it takes anywhere from 4 to $17 \mathrm{~h}$ to isolate DNA, with the yield ranging from 5 to $15 \mu \mathrm{g}$ DNA from 300 $\mu \mathrm{L}$ whole blood. In our experience, as suggested in the Sambrook and Russell protocol (6), eliminating the proteinase $\mathrm{K}$ treatment of 3-16 $\mathrm{h}$ did not yield enough DNA. There are many companies selling kits to isolate DNA from blood. In general, all the kits promise varying yield (5-20 $\mu \mathrm{g}$ from $300 \mu \mathrm{L}$ whole blood) in $30 \mathrm{~min}$ to $1 \mathrm{~h}$.

We routinely isolate genomic DNA from a few samples of human whole blood. Our aim was to isolate DNA economically, rapidly, and with a minimum of toxic solvents. Therefore, we successfully modified the Sambrook and Russell procedure (6). The modification that we introduced is the near complete removal of all the materials of the blood, except the white blood cells, by repeated washing in wash buffer (20 $\mathrm{mM}$ Tris- $\mathrm{HCl}, \mathrm{pH} 7.5$ ), before its lysis in rapid mammalian lysis buffer. This step removed all the contaminating red blood cells and the serum proteins, thereby cutting down the isolation time and stabilizing the yield. This is in contrast to the suspension of white blood cells in $20 \mu \mathrm{L}$ of the leftover supernatant from the single washing step in wash buffer, as suggested in the original protocol (6). The protein released from white blood cells was precipitated by SDS-salt, thus leaving deproteinized DNA in solution. Thus, the need for
Table 1. Amount of Genomic DNA Isolated from Human Blood Samples by This Procedure

\begin{tabular}{|c|c|c|c|c|}
\hline $\begin{array}{l}\text { Row } \\
\text { Number }\end{array}$ & $\begin{array}{c}\text { Blood } \\
\text { Volume }(\mu \mathrm{L})\end{array}$ & $\begin{array}{l}\text { Quantity of } \\
\text { DNA Obtained } \\
(\bar{x} \pm \mathrm{SD} ; \mu \mathrm{g})\end{array}$ & $\begin{array}{l}\text { Quantity of DNA } \\
\text { in } 300 \mu \mathrm{L} \text { Blood } \\
\qquad(\overline{\mathrm{x}} \pm \mathrm{SD} ; \mu \mathrm{g})\end{array}$ & $A_{260} / A_{280}$ \\
\hline 1 & $100(4)^{a, b}$ & $4.04 \pm 0.26$ & $12.11 \pm 0.77$ & $1.67 \pm 0.07$ \\
\hline 2 & $200(4)^{a, b}$ & $8.13 \pm 0.48$ & $12.19 \pm 0.72$ & $1.90 \pm 0.03$ \\
\hline 3 & $300(2)^{a, b}$ & $10.0 \pm 0.71$ & $10.00 \pm 0.71$ & $1.69 \pm 0.01$ \\
\hline 4 & \multicolumn{3}{|c|}{ Average of the Above Three Rows $11.72 \pm 1.12$} & $1.76 \pm 0.12$ \\
\hline 5 & $300(4)^{a, c}$ & $19.50 \pm 2.89$ & $19.50 \pm 2.89$ & $1.78 \pm 0.09$ \\
\hline 6 & $300(4)^{a, c}$ & $17.50 \pm 4.78$ & $17.50 \pm 4.78$ & $1.74 \pm 0.11$ \\
\hline 7 & $300(4)^{a, c}$ & $8.35 \pm 0.87$ & $8.35 \pm 0.87$ & $1.69 \pm 0.03$ \\
\hline 8 & $300(2)^{a, c}$ & $13.00 \pm 0.71$ & $13.00 \pm 0.71$ & $1.73 \pm 0.07$ \\
\hline 9 & $\begin{array}{l}\text { Yield Range } \\
(\bar{x} \pm S D ; \mu g)^{d}\end{array}$ & in $300 \mu \mathrm{L}$ Blood & $8.35 \pm 0.87$ to & $19.50 \pm 2.89$ \\
\hline \multicolumn{5}{|c|}{$\begin{array}{l}\text { aNumber of replicates } \\
\text { bBlood from the same donor } \\
\text { cBlood from different donors and isolated by different individuals } \\
\text { dYield from kits is in the range of } 5-20 \mu \mathrm{g} \text { from } 300 \mu \mathrm{L} \text { whole bloc }\end{array}$} \\
\hline
\end{tabular}

proteinase $\mathrm{K}$ digestion, as described in the original procedure, is obviated. The modified procedure is detailed below. In a $1.5-\mathrm{mL}$ microcentrifuge tube, we

mixed $300 \mu \mathrm{L}$ blood with $1200 \mu \mathrm{L} 20$ $\mathrm{mM}$ Tris- $\mathrm{HCl}, \mathrm{pH} 7.5$, and incubated it at room temperature for $10 \mathrm{~min}$. We centrifuged it for $30 \mathrm{~s}$ at $16000 \times \mathrm{g}$ at

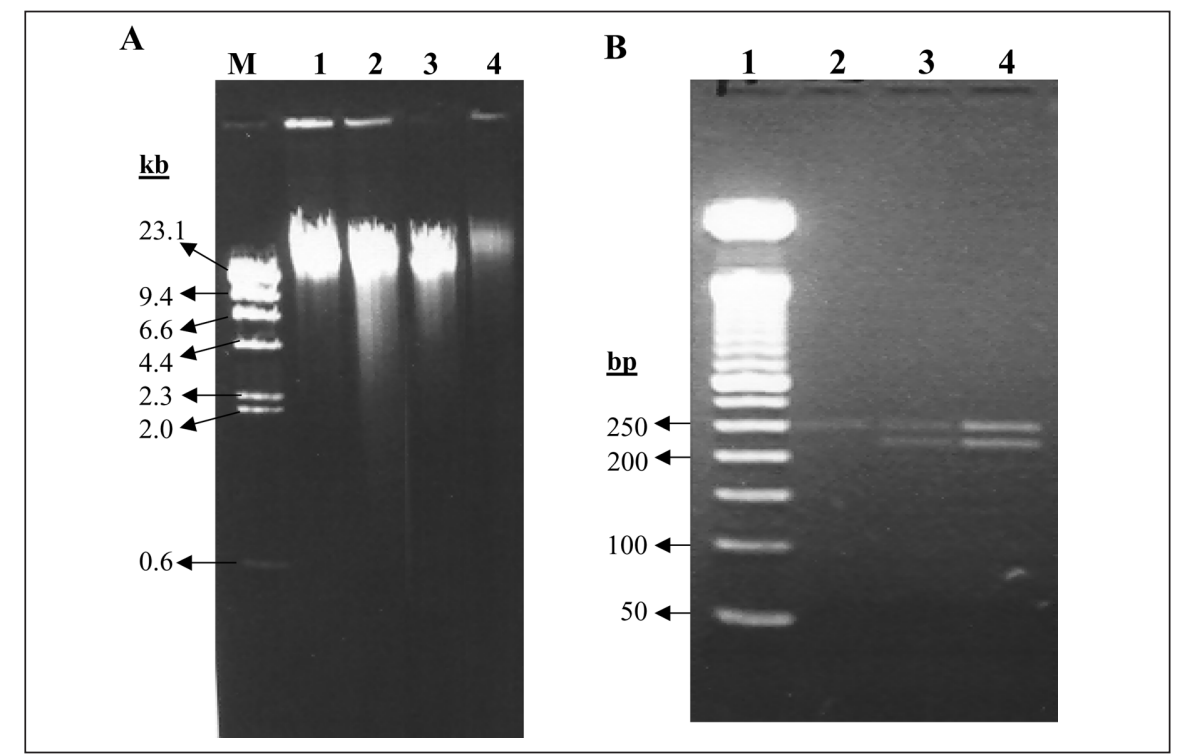

Figure 1. (A) Agarose gel electrophoresis of genomic DNA isolated from whole human blood. About 1 $\mu \mathrm{g}$ of the isolated DNA was analyzed on a $0.8 \%$ agarose gel in $1 \times \mathrm{TBE}$ containing $0.5 \mu \mathrm{g} / \mathrm{mL}$ ethidium bromide. The DNA was electrophoresed at $10 \mathrm{~V} / \mathrm{cm}$ until the bromophenol blue ran to $2-3 \mathrm{~cm}$ from the bottom of the gel. The bands were visualized using a UV transilluminator and photographed. Lane M, high molecular weight marker in kilobases (Bio-Rad Laboratories, Hercules, CA, USA). Lanes 1-3, DNA isolated by this procedure from three different blood samples; lane 4, human umbilical DNA. (B) Agarose gel electrophoresis of PCR products. The upstream region of human TS gene was amplified to analyze polymorphic repeats, as described in the text. Expected product lengths are 208-214 bp for dimeric repeats. The presence of each additional polymorphic repeats increases the size by about $28 \mathrm{bp}$. PCR products were analyzed on $2 \%$ agarose 1000 in $1 \times$ TBE buffer containing $0.5 \mu \mathrm{g} / \mathrm{mL}$ ethidium bromide and processed as described above. Lane 1, 50-bp DNA molecular weight marker (Invitrogen); lane 2, 248-bp trimeric repeat for the $5^{\prime}$ untranslated region; lanes 3 and 4, about 214- and 248-bp dimeric and trimeric repeats. 
room temperature. We resuspended the pellet in $1.5 \mathrm{~mL}$ of the above buffer and washed until the supernatant was nearly clear (2-4 washes) and the pellet was mostly white. After completely removing the wash buffer, we suspended the white blood cell pellet in $600 \mu \mathrm{L}$ icecold $10 \mathrm{mM}$ Tris-HCl, $\mathrm{pH}$ 8.0, $1.0 \mathrm{mM}$ EDTA, $0.1 \%$ SDS and dispersed the pellet using a Kontex pellet disperser on ice. We added DNase-free RNase to a final concentration of $20 \mu \mathrm{g} / \mathrm{mL}$ and incubated at $37^{\circ} \mathrm{C}$ for $30 \mathrm{~min}$. At the end of incubation, we cooled it to room temperature and added $200 \mu \mathrm{L} 3 \mathrm{M}$ sodium acetate, $\mathrm{pH} 5.2$, and mixed thoroughly but gently to form a single phase. We centrifuged at $16000 \times g$ for $3 \mathrm{~min}$ at $4^{\circ} \mathrm{C}$ and collected the supernatant of approximately $800 \mu \mathrm{L}$. We added $600 \mu \mathrm{L}$ isopropanol and mixed gently to precipitate the DNA. We pelleted the DNA by centrifuging at $16000 \times \mathrm{g}$ for $1 \mathrm{~min}$ at room temperature and washed the pellet in $70 \%$ ethanol. We dried and suspended the DNA pellet in water or TE buffer as desired.

Table 1 shows the yield of genomic DNA from fresh and frozen blood samples and from different starting volumes of blood. In our experience, a consistently good yield of genomic DNA was obtained from 100 to $300 \mu \mathrm{L}$ blood. On average, we could isolate $11.72 \pm 1.12 \mu \mathrm{g}$ DNA from $300 \mu \mathrm{L}$ blood from the same donor (Table 1 , row 4). The yield from $50 \mu \mathrm{L}$ starting volume of blood was appreciably low (data not shown). This may be because of the low yield of white blood cells that might have been easily washed off during the repeated $20 \mathrm{mM}$ Tris washes. On average, we obtained $12.99 \pm$ $4.33 \mu \mathrm{g}$ per $300 \mu \mathrm{L}$ blood from different blood samples isolated independently by different individuals. This is $52.95 \pm 13.38 \mu \mathrm{g}$ DNA $/ \mathrm{mL}$ whole blood. This yield is comparable to that of other published procedures $(6,7)$.

The quality of isolated genomic DNA was monitored by absorbance ratio. It is 1.67 to 1.90 (Table 1 , column 5 ), indicating the absence of other protein contaminants. The wavelength scan (data not shown) is identical to that of commercially obtained human DNA. The size of the isolated genomic DNA by this modified procedure was analyzed on a $0.8 \%$ agarose gel. The size of the genomic DNA isolates is above 23 $\mathrm{kb}$ (Figure 1A). This indicates that this procedure yields high-quality DNA.

We routinely isolate genomic DNA from human whole blood by this modified procedure to analyze polymorphic repeats in the $5^{\prime}$ untranslated region of the thymidylate synthetase (TS) gene by PCR (2). The PCR protocol is described briefly here. The polymorphic TS5' upstream region was analyzed by PCR using a forward primer, TS5' Sense $\left(5^{\prime}\right.$ GTGGCTCCTGCGTTTCCCCC-3'), located about $220 \mathrm{bp}$ upstream of the translational start codon, and a reverse primer, TS5' Antisense (5'-GCTCCGAGCCGGCCACAGGCATGGCGCGG$\left.3^{\prime}\right)$, located seven nucleotides upstream of the start codon (2). The reaction mixture contained 50-100 ng isolated DNA as template, 100 pmol each of the primers, $200 \mu \mathrm{mol}$ each dNTPs, 10\% DMSO, and 3.5 U DNA polymerase (High Fidelity PCR system; Roche Applied Science, Indianapolis, IN, USA) in $50 \mu \mathrm{L}$ final reaction volume. The reaction mixture was denatured initially at $94^{\circ} \mathrm{C}$ for $1 \mathrm{~min}$ and then subjected to 25 cycles of denaturation at $94^{\circ} \mathrm{C}$ for $15 \mathrm{~s}$, annealing at $60^{\circ} \mathrm{C}$ for $15 \mathrm{~s}$, and extension at $72^{\circ} \mathrm{C}$ for $30 \mathrm{~s}$. A final extension at $72^{\circ} \mathrm{C}$ was performed for $7 \mathrm{~min}$. The resultant products were analyzed on $2 \%$ agarose-1000 (Invitrogen, Carlsbad, CA, USA) gel following the standard protocol (6). Results (Figure 1B) show very clear bands corresponding to the genotype of the sample analyzed. This proves that the quality of the DNA isolated is good for PCR. For all quality control steps, human umbilical DNA (female) obtained from Sigma (St. Louis, MO, USA) was used.

This modified genomic DNA isolation method eliminated a minimum of 3 $\mathrm{h}$ from the published protocol (6). In this method, all the processing is done in a single tube. Transfer of DNA for precipitation is done only once, thus ensuring the DNA is not handled more than necessary. Using this method, we routinely isolate consistently highquality DNA from whole blood in about $1 \mathrm{~h}$. This procedure also yields 8-20 $\mu \mathrm{g}$ DNA (Table 1, row 9) from 100 to $300 \mu \mathrm{L}$ of both fresh and frozen citrated, EDTA-treated, or heparinized whole blood. Since most of the materials used in this procedure are available in all biochemistry and molecular biology laboratories, the cost of isolation is negligible. There is no downtime to order blood genomic DNA purification kits or other specialty chemicals. Though we have not tested the isolated DNA for other analytical methods such as Southern hybridization, DNA fingerprinting, and RFLP analysis, we do not see any reason why it cannot be used for those purposes $(3,7)$.

\section{REFERENCES}

1.Albarino, C.G. and V. Romanowski. 1994. Phenol extraction revisited: a rapid method for the isolation and preservation of human genomic DNA from whole blood. Mol. Cell Probes 8:423-427.

2.Marsh, S., E.S. Collie-Duguid, T. Li, X. Liu, and H.L. McLeod. 1999. Ethnic variation in the thymidylate synthase enhancer region polymorphism among Caucasian and Asian populations. Genomics 58:310-312.

3.Parzer, S. and C. Mannhalter. 1991. A rapid method for the isolation of genomic DNA from citrated whole blood. Biochem. J. 273(Pt 1):229-231.

4.Robbins, V., M.P. Aguinaga, and M.S. Valenzuela. 1995. Efficient isolation of whole genomic DNA from cell cultures and blood samples. BioTechniques 18:414-418.

5.Rudbeck, L. and J. Dissing. 1998. Rapid, simple alkaline extraction of human genomic DNA from whole blood, buccal epithelial cells, semen and forensic stains for PCR. BioTechniques 25:588-592.

6.Sambrook, J. and D.W. Russell. 2001. Molecular Cloning: A Laboratory Manual. CSH Laboratory Press, Cold Spring Harbor, NY.

7.Wang, L., K. Hirayasu, M. Ishizawa, and Y. Kobayashi. 1994. Purification of genomic DNA from human whole blood by isopropanol-fractionation with concentrated $\mathrm{Nal}$ and SDS. Nucleic Acids Res. 22:1774-1775.

Address correspondence to Dr. Pochi R. Subbarayan, Department of Hematology and Oncology, University of Miami School of Medicine, $1550 \mathrm{NW} 10^{\text {th }}$ Avenue, Fox 431A, Miami, FL 33136, USA. e-mail: spochi@med.miami.edu

Received 7 August 2002; accepted 16 September 2002.

Pochi R. Subbarayan, Malancha Sarkar, and Bach Ardalan University of Miami School of Medicine

Miami, FL, USA 